\title{
USULAN PERBAIKAN LOADING RATE DI FASILITAS AUTOMATIC LINE PACKER MENGGUNAKAN METODE SEVEN TOOLS DAN FAULT TREE ANALYSIS (Studi Kasus: PT. Cemindo Gemilang Gresik)
}

\author{
Ardiansyah Armawan, Deny Andesta, Dzakiyah Widyaningrum \\ Program Studi Teknik Industri - Fakultas Teknik \\ Universitas Muhammadiyah Gresik
}

\begin{abstract}
ABSTRAK
Kinerja loading rate tahun 2017 menunjukkan performa mesin matik yang lebih kecil dari performa mesin manual, hal ini dapat mengganggu target produksi semen sebesar 53 ton/jam pada line packer otomatis. Dari permasalahan ini, faktor-faktor apa saja yang mempengaruhi penurunan otomatis kinerja tingkat pembebanan dan bagaimana perbaikan yang diusulkan.

Untuk dapat mengetahui faktor-faktor yang mempengaruhi penurunan kinerja laju pembebanan otomatis dan usulan perbaikan digunakan metode seven tools and fault tree analysis dan metode seven tools yang digunakan yaitu check sheet, fishbone diagram, map control (kontrol). grafik) dan diagram pareto (analisis pareto). Dari tujuan penelitian ini untuk menentukan faktor-faktor yang menyebabkan laju pembebanan pada pengemas jalur otomatis dan untuk menentukan usulan perbaikan laju pembebanan dengan menggunakan metode tujuh alat dan analisis pohon kesalahan. Untuk dapat mengoptimalkan kinerja laju pembebanan maka diterapkan metode seven tools dan analisis pohon kesalahan dengan bantuan metode $5 \mathrm{~W}+1 \mathrm{H}$.

Dari hasil studi kasus pada PT. Cemindo Gemilang pada bagian dispatch menemukan bahwa pengaruh penurunan laju muat disebabkan oleh beberapa faktor, salah satunya adalah setting truk lama sebesar 23,64\% dan prioritas perbaikan untuk meningkatkan kinerja laju muat. Mengusulkan perbaikan kecepatan muat dengan melakukan pelatihan, membuat regulasi, melakukan sosialisasi, perawatan berkala serta penambahan 8 spout dan $2500 \mathrm{rpm}$.
\end{abstract}

Kata kunci: Seven Tools, Fault Tree Analysis, dan 5 W + 1 H

\section{PENDAHULUAN}

PT. Cemindo Gemilang merupakan salah satu pendatang baru di dunia industri semen di Indonesia yang berdiri sejak tahun 2011. Perusahaan ini memproduksi semen dengan merek dagang Semen Merah Putih. Pabrik pertama sekaligus pabrik pusatnya berlokasi di daerah Bayah, Banten Jawa Barat, dan pabrik yang lain sebagai cabang perusahaan berlokasi di Gresik, Jawa Timur. PT. Cemindo Gemilang yang berlokasi di daerah Gresik, Jawa Timur tersebut baru berdiri pada tahun 2014. PT. Cemindo Gemilang Gresik adalah pabrik penggilingan (grinding plant) dengan kapasitas 1.000 .000 ton per tahun. Jenis Produk dari PT. Cemindo Gemilang terdiri dari 3 jenis yaitu semen, Ready Mix Concrete dan Precast Concrete. Semen Merah

Putih memproduksi Portland Composite Cement (PCC) tersedia dalam dua kemasan kantong $40 \mathrm{~kg}$ dan $50 \mathrm{~kg}$. Dalam proses produksi di PT. Cemindo
Gemilang ada beberapa tahap yaitu , penggilingan (grinding), pembakaran dan pendinginan clinker (burning and cooling), penggilingan akhir (finishing mill) dan pengantongan (packing). Bagian pengantongan (packing) yaitu proses tahap akhir dari produksi semen, dimana dari dalam silo, semen dikirim ke unit pengepakan ataupun langsung dikirim dalam bentuk curah. Pengeluaran semen dari dalam silo dengan memakai sistem campur, artinya semen yang keluar tidak berasal dari satu sisi silo saja, melainkan bergantian dari seluruh bagian silo. Semen dikeluarkan dan dikirimkan ke roto packer yang berjumlah 3 buah roto, lalu selanjutnya dikantongi dalam kemasan $40 \mathrm{~kg}$ atau $50 \mathrm{~kg}$. Dalam pengantongan di roto packer ini mempunyai 8 spout dengan kecepatan $2500 \mathrm{rpm}$. Setelah di roto packer, semen dikirimkan ke line (4 buah) menggunakan conveyor lalu semen 
dikirimkan ke truk menggunakan mesin manual (2 buah) dan mesin automatic (2 buah). Dalam proses pengantongan semen melalui mesin manual menggunakan 2 roto dan 2 line yang dijalankan oleh operator. Serta dalam proses pengantongan semen melalui mesin automatic menggunakan 1 roto dan 2 line yang dijalankan secara auto loader (semi otomatis). Selama proses pengantongan semen tersebut disebut loading rate. Pentingnya performa loading rate yang baik akan meningkatkan jalannya kegiatan perusahaan.Akan tetapi dalam proses pengantongan semen menggunakan mesin automatic mengalami berbagai permasalahan seperti masalah dalam waktu penempatan / memposisikan truk (setting truck), adanya trouble di vibrating dan puley aus, penempatan semen tidak rata, semen pecah (bad damage), sensor kotor, adanya trouble di fan belt, dll. Sehingga dengan adanya permasalahan tersebut mengakibatkan performa mesin automatic menurun atau tidak sesuai dengan standar perusahaan sebesar 53 ton/jam. Hal ini akan mengakibatkan loading rate di automatic line packer menunjukkan performa lebih kecil dari loading rate di manual line packer di tahun 2017.

Salah satu tolak ukur untuk mengetahui apakah perusahaan berhasil dalam upaya perencanaan perbaikan loading rate di automatic line packer adalah jika perusahaan tersebut berhasil mencapai Performa Loading Rate sebesar 53 ton/jam. Akan tetapi kondisi ini sangat sulit untuk dicapai, karena setiap proses loading rate pasti ada masalah walaupun sedikit. Hal ini disebabkan oleh adanya berbagai penyimpangan yang sering terjadi dalam suatu proses pemuatan semen, baik dari faktor manusia, mesin, material dan metode yang digunakan, kejadian ini akan mengurangi kepercayaan konsumen terhadap perusahaan dan mengurangi keuntungan yang bisa didapat. Berbagai cara untuk perbaikan loading rate di automatic line packer, salah satunya dengan metode Seven Tools

dan Fault Tree Analysis. (Fauzi 2017)

\section{METODE}

Studi yang akan digunakan dalam penelitian ini adalah studi deskriptif, yaitu studi untuk mengadakan suatu perbaikan terhadap keadaan terdahulu yang bertujuan untuk mencari dan mengumpulkan sejumlah data guna mendapatkan suatu gambaran fakta-fakta yang jelas tentang berbagai hal, keadaan situasi yang ada pada perusahaan. Penelitian ini dilakukan terhadap suatu permasalahan yang ada dengan tujuan untuk memperoleh hasil yang lebih baik dari sebelumnya karena didalamnya digunakan suatu metodemetode atau teknik-teknik tertentu serta data yang diperoleh juga memenuhi syarat yaitu : faktual, obyektif dan relevan.

Loading rate dalam permasalahan ini, untuk memperoleh loading rate pada packer loader yang lebih baik dari sebelumnya, sehingga dapat mengurangi terjadinya antrian truk dan memperbaiki kesalahan - kesalahan loading rate yang terjadi akibat ketidakoptimalan loading rate di packer loader khususnya di automatic packer loader sehingga mengakibatkan Performa Loading Rate menurun atau tidak sesuai dengan target perusahaan.

Pada uraian kerangka pemecahan masalah akan dijelaskan langkah - langkah yang akan dilakukan untuk mengidentifikasi dan memecahkan permasalahan dengan jelas pada objek penelitian.

\section{Studi pedahuluan}

a. Studi pustaka

Studi pustaka digunakan sebagai landasan teori ataupun metode yang akan dipakai dalam penelitian. Sebelum melakukan pengambilan data dilapangan, terlebih dahulu metode metode apa yang akan dipergunakan dengan berpedoman pada literatur - literatur yang sudah ada serta informasi lain, seperti buku, penelitian terdahulu, majalah - majalah ilmiah dan surat kabar. Permasalahan ini ditekankan pada upaya perbaikan loading rate di packer loader khususnya di automatic packer loader.

b. Studi lapangan

Studi lapangan dilakukan dengan tujuan untuk dapat melihat secara jelas kondisi atau sistem perusahaan dan mencatat permasalahan yang ada, keputusan memecahkannya dan selanjutnya dianalisa.

2. Identifikasi masalah

Setelah dilakukan studi pustaka dan studi lapangan, maka dapat diidentifikasikan 
masalah - masalah yang berkaitan dengan pengendalian kualitas dengan literatur yang diperlukan. Kemudian dari identifikasi masalah tersebut dapat dirumuskan masalah yang akan diteliti. Perumusan masalah tersebut merupakan titik awal untuk melihat permasalahan yang akan muncul yaitu dengan adanya ketidakoptimalan loading rate di packer loader khususnya di automatic packer loader. Untuk mengatasinya, diperlukan metode-metode perbaikan loading rate yang tujuannya mengoptimalkan loading rate sehingga Performa Loading Rate meningkat atau sesuai dengan target perusahaan.

3. Tujuan penelitian

Tujuan harus di tetapkan agar penelitian yang dilakukan tidak menyimpang dan dapat dicapai dengan menggunakan cara - cara yang efisien dan akurat.

4. Pengumpulan Data

Metode pengumpulan data dalam kegiatan penelitian bertujuan untuk mengungkap fakta mengenai variabel yang diteliti. Tujuan tersebut harus dicapai dengan menggunakan cara - cara yang efisien dan akurat.

Data yang didapat dari meneliti, memilah, mengelompokkan data historis selama 1 tahun yang di peroleh dari dokumen perusahaan, adapun data-datanya sebagai berikut :

a. Data Loading Rate, yaitu melakukan pengumpulan data loading rate pada periode 2017 yang menunjukkan performance loading rate di packer loader belum bisa optimal, khususnya di automatic packer loader hanya mencapai 44.65 ton/jam, sedangkan di line manual packer loader sudah bisa mencapai 56.43 ton/jam.

b. Data Loading Rate di automatic line packer, yaitu pengumpulan data loading rate di automatic line packer pada awal tahun 2018 di bulan Januari hingga Maret 2018.

c. Data jenis permasalahan loading rate di automatic line packer, yaitu pengelompokkan data loading rate di automatic line packer dengan melihat lembar pemeriksaan dari perusahaan pada bulan Januari hingga Maret 2018.

d. Data jumlah permasalahan loading rate di automatic line packer, yaitu penjumlahan data loading rate di automatic line packer dari data jenis permasalahan lalu di rangking data tersebeut sehingga mengetahui permasalahan yang memiliki persentasi yang besar.

\section{Pengolahan Data}

a. Pengelompokkan data jenis permasalahan loading rate di automatic line packer (dengan Check Sheet /lembar pemeriksaan) yaitu, setealah mengetahui permasalahan pada setiap proses loading rate maka dikelompokkan kedalam jenis permasalahan dengan menggunakkan Check Sheet. Tujuan utama dari penggunaan Check Sheet adalah untuk menjamin data yang telah dikumpulkan dengan teliti dan akurat oleh operator. Data tersebut harus dikumpulkan mulai dari proses awal hingga akhir sampai diketahui jenis- jenis cacat yang didapat kemudian dengan cara seperti itu data yang dihasilkan dicatat pada lembar yang tersedia dengan mengelompokkan jenis cacat dan menghitung jumlah cacat tersebut dan dapat dengan secara mudah untuk dianalisa. Bentuk dari uji lembaran ini digunakan tersendiri dalam situasi yang dirancang oleh tim.

b. Mencari penyebab permasalahan loading rate di automatic line packer (dengan Metode Seven Tools) yaitu, untuk mencari penyebab terjadinya ketidakoptimalan loading rate di packer loader khususnya di automatic line packer loader setelah data- data terkumpul menggunakan alat bantu Seven tools yaitu Fishbone diagram. Dengan penjelasan sebagai berikut:

- Diagram sebab akibat (fishbone diagram)

Diagram ini berguna untuk memperlihatkan faktor - faktor utama yang berpengaruh pada kualitas dan mempunyai akibat pada masalah yang dihadapi. Untuk mencari faktor-faktor penyebab terjadinya penyimpangan kualitas hasil kerja, maka orang akan selalu mendapatkan bahwa ada 5 (lima) faktor penyebab utama yang signifikan yang perlu diperhatikan yaitu:

$>$ Man (Manusia)

$>$ Material (Bahan baku)

$>$ Machine (Mesin dan peralatan kerja) 
$>$ Method (Metode kerja)

$>$ Environment (Lingkungan) Diagram sebab akibat ini sangat bermanfaat untuk mencari faktor - faktor penyebab sedetaildetailnya (uncountabel) dan mencari hubungannya dengan penyimpangan kualitas kerja yang ditimbulkannya.

- Control Chart

Control Chart menunjukkan adanya perubahan data dari waktu ke waktu, tetapi tidak menunjukkan penyebab penyimpangan meskipun penyimpangan itu akan terlihat pada peta kendali.

Untuk menentukan penyebab utama dalam menganalisa masalah terjadinya defect dapat menggunakan pareto dengan penjelasan sebagai berikut:

\section{- Diagram Pareto}

Diagram pareto dibuat untuk menemukan masalah atau penyebab terjadinya cacat yang merupakan kunci dalam penyelesaian masalah dan perbandingan terhadap keseluruhan. Dengan mengetahui penyebab-penyebab yang dominan yang seharusnya diatasi, maka kita akan menetapkan prioritas perbaikan. Misalnya hal yang dominan pada defect yang terjadi adalah Sheet screat. Kegunaan dari diagram pareto adalah :

a. Menunjukkan persoalan utama yang dominan dan perlu segera diatasi.

b. Menyatakan perbandingan masingmasing persoalan yang ada dan kumulatif secara keseluruhan.

c. Menunjukkan tingkat perbaikan setelah tindakan koreksi dilakukan pada daerah yang terbatas.

d. Menunjukkan perbandingan masingmasing persoalan sebelum dan sesudah perbaikan

6. Analisis dan interpretasi

Pada tahap ini dilakukan proses analisis dari hasil perhitungan yang telah didapat dan pembahasan terhadap hasil dari uraian penyebab ketidakoptimalan loading rate di packer loader khususnya di automatic line packer loader yang paling sering muncul dapat di temukan faktor penyebab yang paling besar untuk selanjutnya dapat diketahui apakah ada perubahan yang berarti dari usulan dan tindakan perbaikan yang dilakukan dari analisis data bulan Januari s/d Maret 2018 untuk selanjutnya faktor penyebab yang paling besar tersebut dilakukan analisa kembali lebih mendalam dengan metode FTA untuk mengetahui akar permasalahan yang menjadi penyebab terjadinya faktor penyebab tersebut, yang nantinya akan memunculkan rancangan usulan perbaikan loading rate di automatic line packer menggunakan metode $5 \mathrm{~W}+1 \mathrm{H}$ yang berisikan penjelasan dari hasil yang telah didapat dari informasi - informasi dalam bentuk tabel dan gambar yang menunjukkan hasil dari penelitian.

7. Kesimpulan dan Saran

Dari langkah - langkah di atas, maka dapat dibuat suatu kesimpulan mengenai proses loading rate yang berjalan. Apakah proses loading rate dalam keadaan terkendali atau tidak dan bagaimana pola (penyebaran) data yang dihasilkan dan saran - saran yang ditujukan bagi perusahaan demi peningkatan kualitas loading rate berdasarkan prosedur prosedur pengolahan data dan analisa data.

\section{HASIL PENELITIAN}

Data check sheet untuk mengetahui area permasalahan berdasarkan frekuensi dari jenis atau penyebab dan mengambil keputusan untuk melakukan perbaikan atau tidak terhadap loading rate di automatic line packer dengan mencatat frekuensi yang dapat dilihat pada table 1 .

Tabel 1

Hasil Check Sheet / Lembar Pemeriksaan

\begin{tabular}{|c|c|c|c|}
\hline No & Trouble & Exekuensi & Score \\
\hline 1 & Truck setting & 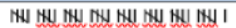 & 41 \\
\hline 2 & $\begin{array}{l}\text { Trouble mesin (Automatic } \\
\text { loading machine) }\end{array}$ & NN IIII & 9 \\
\hline 3 & $\begin{array}{l}\text { Trouble mesin (Jalur roto } \\
\text { packer \& pengisian bin) }\end{array}$ & 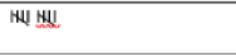 & 10 \\
\hline 4 & $\begin{array}{l}\text { Trouble mesin (Jalur } \\
\text { conveyor belt \& roller) }\end{array}$ & Nㅣ 씬. & 9 \\
\hline 5 & Bag damage & 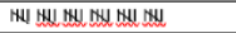 & 30 \\
\hline 6 & Trouble personel & 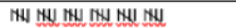 & 30 \\
\hline 7 & Trouble pengisian & 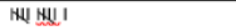 & 11 \\
\hline 8 & Kondisi lingkungan kerja & HN 씬. & 14 \\
\hline 9 & Empty bag preparation & II & 2 \\
\hline \multicolumn{3}{|c|}{ Total } & 156 \\
\hline
\end{tabular}


Data di atas berdasarkan pada lembar pemeriksaan pada bulan Januari 2018, menunjukkan sering terjadinya trouble pada setting truck sebanyak 41 . Maka perlu adanya perbaikan pada truck setting.

Diagram pareto merupakan diagram yang mengggambarkan penyebab loading rate di automatic line packer dengan diurutkan berdasarkan persentase terbesar kemudian dihitung presentase kumulatif sehingga diketahui prioritas perbaikan yang akan dilakukan. Hasil perhitungan kumulatif dan persentase kumulatif dapat dilihat pada tabel 2 .

Tabel 2

Hasil Perhitungan Kumulatif Dan Presentase Kumulatif

\begin{tabular}{|c|c|c|c|c|c|}
\hline $\begin{array}{l}\text { N } \\
\text { o. }\end{array}$ & $\begin{array}{c}\text { Permasala } \\
\text { han }\end{array}$ & $\begin{array}{l}\text { Avera } \\
\text { ge }\end{array}$ & $\begin{array}{c}\text { Comulat } \\
\text { ive }\end{array}$ & $\begin{array}{c}\% \\
\text { Comulat } \\
\text { ive }\end{array}$ & Dar \\
\hline 1 & $\begin{array}{l}\text { Truck } \\
\text { setting }\end{array}$ & 43,28 & 43,28 & $23,64 \%$ & \\
\hline 2 & $\begin{array}{l}\text { Trouble } \\
\text { automatic } \\
\text { loading } \\
\text { machine }\end{array}$ & 39,95 & 83,23 & $45,46 \%$ & $\mathrm{ii}$ \\
\hline 3 & $\begin{array}{l}\text { Trouble } \\
\text { roto packer } \\
\& \\
\text { pengisian } \\
\text { bin }\end{array}$ & 26,63 & 109,87 & $60,01 \%$ & kun \\
\hline 4 & $\begin{array}{l}\text { Trouble } \\
\text { jalur } \\
\text { conveyor }\end{array}$ & 22,20 & 132,06 & $72,13 \%$ & da \\
\hline & belt \& roller & & & & \\
\hline 5 & $\begin{array}{l}\text { Bag } \\
\text { damage }\end{array}$ & 19,90 & 151,96 & $83,00 \%$ & un \\
\hline 6 & $\begin{array}{l}\text { Trouble } \\
\text { personel }\end{array}$ & 16,88 & 168,84 & $92,22 \%$ & $\begin{array}{r}\text { seb } \\
\text { sa }\end{array}$ \\
\hline 7 & $\begin{array}{l}\text { Trouble } \\
\text { pengisian }\end{array}$ & 7,43 & 176,28 & $96,28 \%$ & $4 \%$ \\
\hline 8 & $\begin{array}{l}\text { Kondisi } \\
\text { lingkungan } \\
\text { kerja }\end{array}$ & 6,10 & 182,37 & $99,61 \%$ & ter \\
\hline 9 & $\begin{array}{l}\text { Empty bag } \\
\text { preparation }\end{array}$ & 0,71 & 183,08 & $100,00 \%$ & at \\
\hline
\end{tabular}

Setelah melakukan perhitungan kumulatif dan persentase kumulatif, maka tahap selanjutnya membuat diagram pareto sebagai berikut :

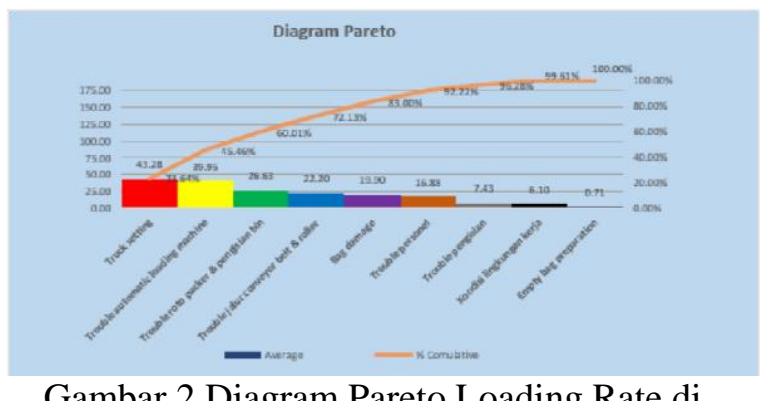

Gambar 2 Diagram Pareto Loading Rate di Automatic

Berdasarkan tampilan output diatas, dapat diketahui bahwa menurunnya performa loading rate didominasi oleh truck setting, trouble automatic loading machine, trouble roto packer \& pengisian bin, trouble jalur conveyor velt $\&$ roller dan bad damage. Jadi sebaiknya perbaikan dapat dilakukan dengan memfokuskan pada truck setting karena paling dominan atau terbesar.

Diagram pareto menunjukkan bahwa penyebab terbesar terjadinya loading rate di automatic line packer adalah truck setting, sehingga dilakukan analisa penyebab kecacatan dengan menggunakan diagram sebab akibat. Pada penelitian ini masalah yang menjadi pangkal pada fishbone diagram adalah truck setting yang terjadi pada proses loading rate di automatic line packer. Dari pangkal masalah ini akan dianalisis penyebab 
- penyebab terjadinya masalah ini dari cabang hingga ke akar sehingga didapatkan akar permasalahan utama yang kemudian dipikirkan apakah langkah perbaikan untuk hal tersebut. Menurut hasil diagram pareto, diketahui bahwa

menurunnya performa loading rate didominasi oleh setting truck. Gambar 3 berikut adalah fishbone diagram dari setting truck.

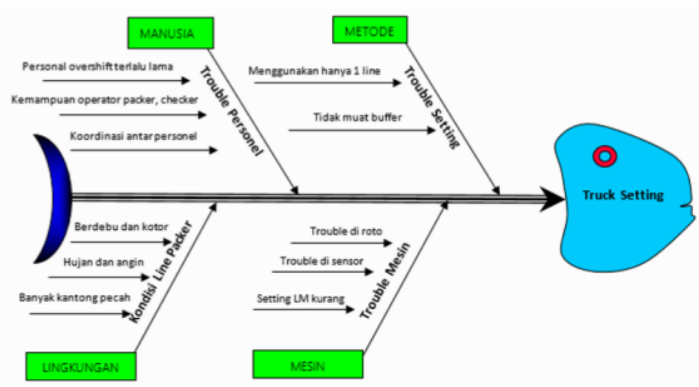

Gambar 3 Diagram Fishbone Loading rate di Automatic

Berikut ini akan ditampilkan potensial problem dan potensial root cause dari hasil Fishbone Diagram diatas.

Tabel 3
Tabel potensial problem dan potensial root cause

Berdasarkan tabel diatas, dapat dilihat secara jelas mengenai penyebab - penyebab serta akar

\begin{tabular}{|c|c|c|c|}
\hline \multirow[t]{3}{*}{ Lingkungan } & \multirow{3}{*}{$\begin{array}{l}\text { Kondisi } \\
\text { Line } \\
\text { Packer }\end{array}$} & Berdebu dan kotor & $\begin{array}{l}\text { Bekas dari semen } \\
\text { defect }\end{array}$ \\
\hline & & Hujan dan angin & $\begin{array}{l}\text { Musim } \\
\text { Hujan }\end{array}$ \\
\hline & & $\begin{array}{l}\text { Banyak kantong } \\
\text { pecah }\end{array}$ & $\begin{array}{l}\text { Kualitas kantong } \\
\text { kurang baik }\end{array}$ \\
\hline \multirow[t]{3}{*}{ Mesin } & \multirow[t]{3}{*}{$\begin{array}{l}\text { Trouble } \\
\text { Mesin }\end{array}$} & Trouble di roto & $\begin{array}{l}\text { Hanya } \\
\text { menggunak } \\
\text { an } 6 \text { spout dan } \\
\text { kecepatan } 2600 \\
\text { rpm }\end{array}$ \\
\hline & & Trouble di sensor & Akibat dari debu \\
\hline & & Setting LM kurang & $\begin{array}{l}\text { Akibat dari } \\
\text { personel } \\
\text { maintenanc e } \\
\text { yang kurang } \\
\text { rutin dalam } \\
\text { pemeliharaa n di } \\
\text { LM }\end{array}$ \\
\hline Faktor & \multicolumn{2}{|c|}{ Potensial Problem } & $\begin{array}{r}\text { Potensial } \\
\text { Root } \\
\text { Couse }\end{array}$ \\
\hline \multirow[t]{3}{*}{ Manusia } & \multirow[t]{3}{*}{$\begin{array}{l}\text { Trouble } \\
\text { Personel }\end{array}$} & $\begin{array}{l}\text { Personal overshift } \\
\text { terlalu lama }\end{array}$ & $\begin{array}{l}\text { Personel datang } \\
\text { terlambat dan } \\
\text { istirahat yang } \\
\text { kurang tepat } \\
\text { waktu. }\end{array}$ \\
\hline & & $\begin{array}{l}\text { Kemampuan } \\
\text { operator packer dan } \\
\text { checker kurang }\end{array}$ & $\begin{array}{l}\text { Kurangnya } \\
\text { pengalaman dalam } \\
\text { mengoperas ikan } \\
\text { mesin automatic. }\end{array}$ \\
\hline & & $\begin{array}{l}\text { Koordinasi kurang } \\
\text { antar personel }\end{array}$ & $\begin{array}{l}\text { Seringnya } \\
\text { alat } \\
\text { komunikasi trouble } \\
\text { atau gangguan } \\
\text { signal. }\end{array}$ \\
\hline \multirow[t]{2}{*}{ Metode } & \multirow[t]{2}{*}{$\begin{array}{l}\text { Trouble } \\
\text { Setting }\end{array}$} & $\begin{array}{l}\text { Menggunakan hanya } 1 \\
\text { line terus }\end{array}$ & $\begin{array}{l}\text { Mesin sering } \\
\text { trouble sehingga } \\
\text { menggunak } \\
\text { an satu mesin dan } \\
1 \text { line. }\end{array}$ \\
\hline & & Tidak muat buffer & $\begin{array}{l}\text { Truk tidak } \\
\text { menggunak } \\
\text { an buffer dan } \\
\text { apabila } \\
\text { menggunak } \\
\text { an buffer } \\
\text { akan memakan } \\
\text { waktu untuk } \\
\text { setting truck }\end{array}$ \\
\hline
\end{tabular}


penyebab masalah yang terjadi sehingga menimbulkan setting truck tidak optimal yang mempengaruhi jalannya loading rate di automatic line packer.

Peta kendali yang digunakan untuk menganalisis proposi lamanya setting truck adalah peta Xbar-R. Peta Xbar-R yaitu peta yang digunakan untuk melihat proporsi jumlah lamanya setting truck per hari terhadap kelompok sampel yang sedang diinspeksi.

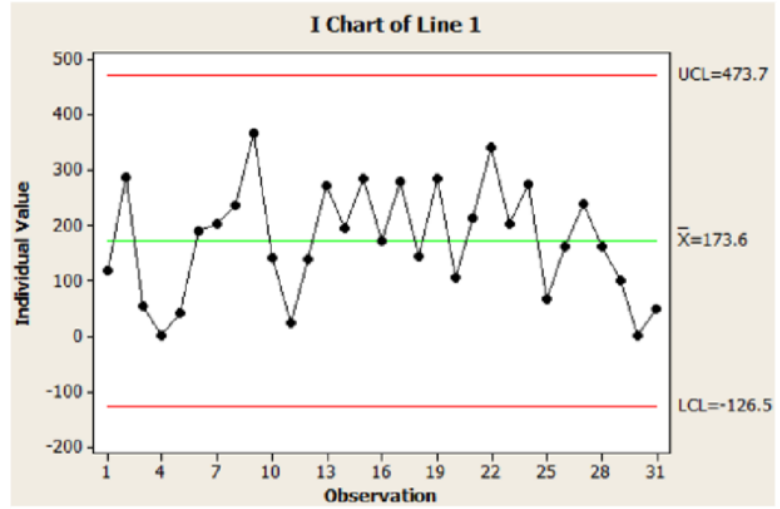

Gambar 4 Diagram Peta Individual Setting Truck Line 1

Berdasarkan peta kendali, dapat diperoleh bahwa semua titik masuk dalam batas kendali dimana nilai mean setting truck di Line 1 (X) adalah 173,6 , batas pengendali atas (UCL) adalah 473,7 dan batas pengendali bawah (LCL) adalah 126,5.

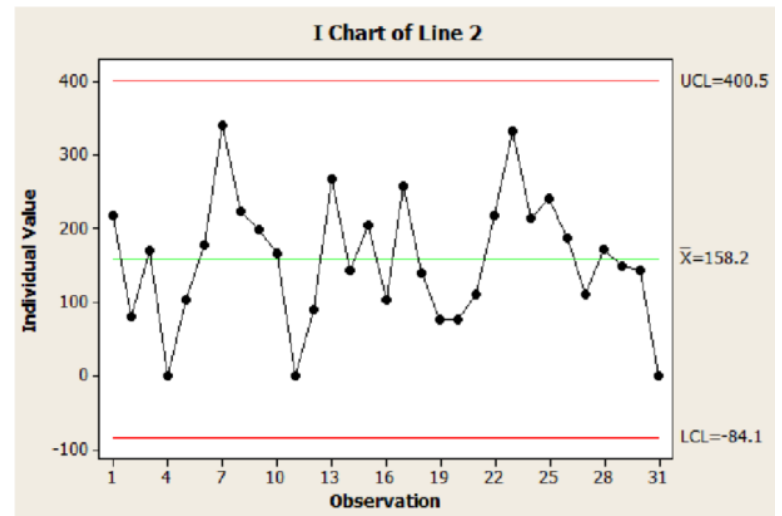

Gambar 5 Diagram Peta Individual Setting Truck Line 2

Berdasarkan peta kendali, dapat diperoleh bahwa semua titik masuk dalam batas kendali dimana nilai mean setting truck di Line 2 (X) adalah 158,2, batas pengendali atas (UCL) adalah 400,5 dan batas pengendali bawah (LCL) adalah 84,1.
Setelah dilakukan pengolahan data seven tools, maka ditemukan jenis - jenis permasalahan yang sering terjadi pada loading rate yaitu disebabkan truck setting $(23,64 \%)$, trouble automatic loading machine $(21,82 \%)$, Trouble roto packer \& pengisian bin $(14,55 \%)$, trouble jalur conveyor belt \& roller $(12,12 \%)$, bag damage $(10,87 \%)$, trouble personel $(9,22 \%)$, trouble pengisian $(4,06 \%)$, kondisi lingkungan kerja $(3,33 \%)$ dan Empty bag preparation $(0,39 \%)$.

Setelah itu tahap selanjutnya membangun pohon kesalahan (fault tree) yaitu :

Langkah pertama, menentukan tujuan yang ingin dicapai dari FTA. Tujuan pembuatan fault tree analysis disini yaitu untuk mencari penyebabpenyebab setting truck di automatic line packer sehingga hilangnya waktu tunggu truck dan menyebabkan menurunnya performa lamanya proses loading rate.

Langkah kedua, mendefinisikan top event. Karena kondisi awal dari sistem adalah pada saat proses setting truck yang memakan waktu yang lama atau tidak sesuai keinginan perusahaan, maka kita memilih top event yaitu pada saat - Setting Truckll. Setelahnya dimulai membuat struktur dari fault tree.

Langkah ketiga. Mendefinisikan basic event dengan cara menggunakan hasil brainstorming dengan mandor untuk selanjutnya digunakan sebagai butir pertanyaan dalam kuesioner (Lampiran II).

Langkah keempat. Setelah didapatkan hasil brainstorming, maka melakukan perhitungan total dari bobot kuesioner pada faktor - faktor penyebab lamanya setting truck di automatic line packer. Hasilnya perhitungan total bobot kuesioner dapat dilihat pada tabel 4 .

Tabel 4

Tabel Hasil Perhitungan Total Bobot Kuesioner

\begin{tabular}{|c|l|l|c|c|}
\hline No & Faktor & Pertanyaan & Nilai & Rank \\
\hline 1 & $\begin{array}{l}\text { Lingkun } \\
\text { gan }\end{array}$ & $\begin{array}{l}\text { Cuaca saat } \\
\text { musim hujan }\end{array}$ & 12 & X \\
\hline 2 & Manusia & $\begin{array}{l}\text { Sopir tidak } \\
\text { mengerti line / } \\
\text { garis kuning }\end{array}$ & 24 & IV \\
\hline
\end{tabular}




\begin{tabular}{|c|l|l|c|c|}
\cline { 3 - 5 } & & $\begin{array}{l}\text { Personel kurang } \\
\text { berpengalaman }\end{array}$ & 15 & IX \\
\hline 3 & Metode & $\begin{array}{l}\text { Pergantian shift } \\
\text { yang } \\
\text { tidak tepat } \\
\text { waktu }\end{array}$ & 24 & III \\
\hline & $\begin{array}{l}\text { Alat } \\
\text { kebersihan } \\
\text { kurang }\end{array}$ & 16 & VIII \\
\hline
\end{tabular}

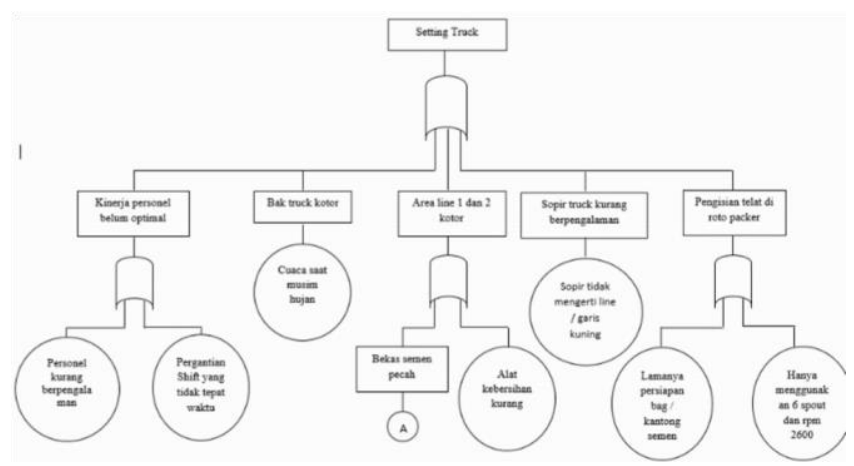

Gambar 6 Fault Tree Analysis Truck Setting

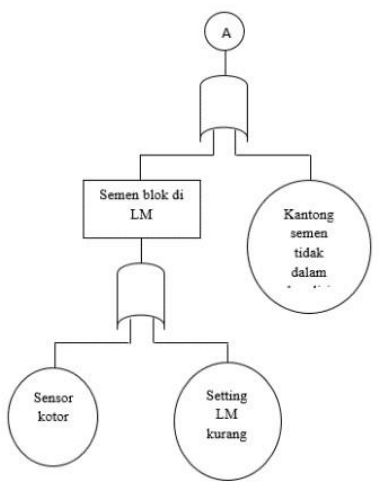

Gambar 6 Fault Tree Analysis Truck Setting

(Lanjutan)

\begin{tabular}{|l|l|l|c|c|}
\cline { 3 - 5 } & & $\begin{array}{l}\text { Lamanya } \\
\text { persiapan bag / } \\
\text { kantong semen }\end{array}$ & 29 & II \\
\hline 4 & Mesin & $\begin{array}{l}\text { Hanya } \\
\text { menggunakan } \\
6 \text { spout dan } \\
\text { rpm 2600 }\end{array}$ & 30 & I \\
\hline
\end{tabular}

\begin{tabular}{|c|c|c|c|}
\hline & Sensor kotor & 22 & $\mathrm{~V}$ \\
\hline & $\begin{array}{l}\text { Setting LM } \\
\text { kurang }\end{array}$ & 21 & VI \\
\hline 5 & $\begin{array}{l}\text { Kantong } \\
\text { semen tidak } \\
\text { dalam kondisi } \\
\text { baik }\end{array}$ & 18 & VII \\
\hline
\end{tabular}

Langkah kelima. Memulai membuat fault tree yaitu symbol kejadian, symbol gerbang dan symbol transfer. Simbol kejadian adalah symbol yang berisi kejadian pada system yang dapat digambarkan dengan bentuk lingkaran, persegi dan yang lainnya, yang mempunyai arti masingmasiing. Contoh dari symbol kejadian adalah intermediate event dan basic event. Sedangkan untuk symbol gerbang, menyatakan hubungan kejadian input yang mengarah pada kejadian output. Hubungan tersebut dimulai dari top event sampai ke event yang paling mendasar. Contoh dari symbol gerbang adalah AND dan OR. Setelah menganalisis masing - masing factor dalam cause and effect diagram kemudian dicari kemungkinan yang menjadi top event. Setelah dilakukan analisis maka yang menjadi top event adalah setting truck .

Setelah tersusun gerbang logika, maka tahap selanjutnya adalah mengubah gerbang logika ke dalam bentuk cut sets. Misalkan :

$\mathrm{T}$ adalah top event

$P$ adalah primary event (basic event)

$\mathrm{G}$ adalah intermediate event

$\mathrm{S} \quad$ adalah undeveloped event

Maka didapatkan bentuk cut sets yang dapat dilihat pada tabel 5.

Tabel 5

Tabel Cut Sets Setting Truck 
Setelah didapatkan simbol cut set maka membuat fault tree yang dapat dilihat pada gambar 7 .

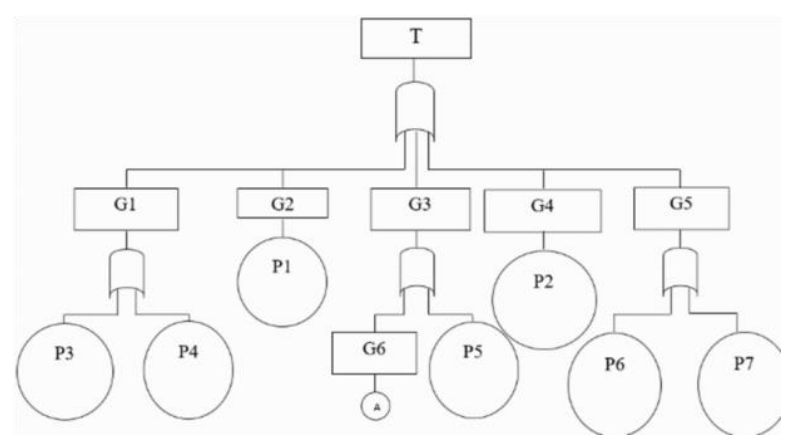

Gambar 7 Cut Sets Truck Setting

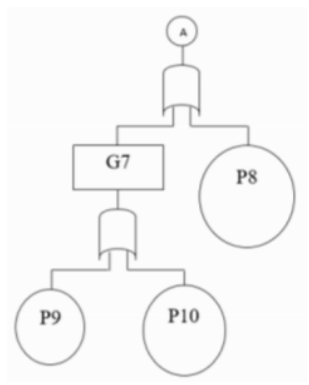

Gambar 7 Cut Sets Truck Setting (Lanjutan)

Dari gambar diatas bisa didapatkan persamaan Booleannya sebagai berikut:

$$
\begin{array}{ll}
\mathrm{T} & =\mathrm{G} 1+\mathrm{G} 2+\mathrm{G} 3+\mathrm{G} 4+\mathrm{G} 5 \\
\mathrm{G} 1 & =\mathrm{P} 3+\mathrm{P} 4 \\
\mathrm{G} 2 & =\mathrm{P} 1 \\
\mathrm{G} 3 & =\mathrm{G} 6+\mathrm{P} 5 \\
\mathrm{G} 4 & =\mathrm{P} 2 \\
\mathrm{G} 5 & =\mathrm{P} 6+\mathrm{P} 7 \\
\mathrm{G} 6 & =\mathrm{G} 7+\mathrm{P} 8 \\
\mathrm{G} 7 & =\mathrm{P} 9+\mathrm{P} 10
\end{array}
$$

\begin{tabular}{|c|c|c|}
\hline No. & Cut Sets & Keterangan \\
\hline 1 & $\mathrm{~T}$ & Lamanya Setting Truck \\
\hline 2 & $\mathrm{P} 1$ & Cuaca saat musim hujan \\
\hline 3 & $\mathrm{P} 2$ & $\begin{array}{l}\text { Sopir tidak mengerti line / } \\
\text { garis kuning }\end{array}$ \\
\hline 4 & $\overline{\mathrm{P} 3}$ & $\begin{array}{l}\text { Personel kurang } \\
\text { berpengalaman }\end{array}$ \\
\hline 5 & $\mathrm{P} 4$ & $\begin{array}{l}\text { Pergantian shift yang tidak } \\
\text { tepat waktu }\end{array}$ \\
\hline 6 & $\overline{\mathrm{P} 5}$ & Alat kebersihan kurang \\
\hline 7 & P6 & $\begin{array}{l}\text { Lamanya persiapan bag / } \\
\text { kantong semen }\end{array}$ \\
\hline 8 & $\mathrm{P} 7$ & $\begin{array}{l}\text { Hanya menggunakan } 6 \\
\text { spout dan rpm } 2600\end{array}$ \\
\hline 9 & P8 & $\begin{array}{l}\text { Kantong semen tidak dalam } \\
\text { kondisi baik }\end{array}$ \\
\hline 10 & P9 & Sensor kotor \\
\hline 11 & $\mathrm{P} 10$ & Setting LM kurang \\
\hline 12 & G1 & $\begin{array}{l}\text { Kinerja personel } \\
\text { belum optimal }\end{array}$ \\
\hline 13 & $\mathrm{G} 2$ & Bak truck kotor \\
\hline 14 & G3 & Area line 1 dan 2 kotor \\
\hline 15 & G4 & $\begin{array}{l}\text { Sopir truck kurang } \\
\text { berpengalaman }\end{array}$ \\
\hline 16 & G5 & $\begin{array}{c}\text { Pengisian telat di } \\
\text { roto packer }\end{array}$ \\
\hline 17 & G6 & Bekas semen pecah \\
\hline 18 & G7 & Semen blok di LM \\
\hline \multicolumn{3}{|c|}{$\begin{array}{l}=\mathrm{P} 3+\mathrm{P} 4+\mathrm{P} 1+\mathrm{G} 6+\mathrm{P} 5+\mathrm{G} 4+\mathrm{G} 5 \\
(\text { karena } \mathrm{G} 4=\mathrm{P} 2) \\
\quad=\mathrm{P} 3+\mathrm{P} 4+\mathrm{P} 1+\mathrm{G} 6+\mathrm{P} 5+\mathrm{P} 2+ \\
\mathrm{G} 5 \text { (karena G5 }=\mathrm{P} 6+\mathrm{P} 7) \\
\quad=\mathrm{P} 3+\mathrm{P} 4+\mathrm{P} 1+\mathrm{G} 6+\mathrm{P} 5+\mathrm{P} 2+ \\
\mathrm{P} 6+\mathrm{P} 7(\text { karena } \mathrm{G} 6=\mathrm{G} 7+\mathrm{P} 8) \\
=\mathrm{P} 3+\mathrm{P} 4+\mathrm{P} 1+\mathrm{G} 7+\mathrm{P} 8+\mathrm{P} 5+\mathrm{P} 2+\mathrm{P} 6 \\
+\mathrm{P} 7(\text { karena } \mathrm{G} 7=\mathrm{P} 9+\end{array}$} \\
\hline
\end{tabular}

Setelah mendapatkan Booleannya maka mensubtitusikan menjadi

$$
\begin{aligned}
& \mathrm{T} \quad=\mathrm{G} 1+\mathrm{G} 2+\mathrm{G} 3+\mathrm{G} 4+\mathrm{G} 5 \\
& (\text { karena } \mathrm{G} 1=\mathrm{P} 3+\mathrm{P} 4) \\
& \quad=\mathrm{P} 3+\mathrm{P} 4+\mathrm{G} 2+\mathrm{G} 3+\mathrm{G} 4+\mathrm{G} 5 \\
& (\text { karena } \mathrm{G} 2=\mathrm{P} 1) \\
& \quad=\mathrm{P} 3+\mathrm{P} 4+\mathrm{P} 1+\mathrm{G} 3+\mathrm{G} 4+\mathrm{G} 5 \\
& (\text { karena G3 }=\mathrm{G} 6+\mathrm{P} 5)
\end{aligned}
$$




$$
\begin{aligned}
& \mathrm{P} 10) \\
& =\mathrm{P} 3+\mathrm{P} 4+\mathrm{P} 1+\mathrm{P} 9+\mathrm{P} 10+\mathrm{P} 8+\mathrm{P} 5 \\
& +\mathrm{P} 2+\mathrm{P} 6+\mathrm{P} 7
\end{aligned}
$$

Maka minimal cut sets dari gambar...Adalah $\{\mathrm{P} 1\},\{\mathrm{P} 2\},\{\mathrm{P} 3\},\{\mathrm{P} 4\},\{\mathrm{P} 5\},\{\mathrm{P} 6\},\{\mathrm{P} 7\}$, $\{\mathrm{P} 8\},\{\mathrm{P} 9\},\{\mathrm{P} 10\}$.

Dari minimal cut sets dapat diketahui berapa banyak kejadian yang dapat berlangsung menyebabkan top event terjadi. Hasil analisis kualitatif dari lamanya setting truck adalah top event terjadi jika kejadian di bawah ini terjadi:

- Cuaca saat musim hujan berpengaruh pada saat proses setting truck yang mengakibatkan semen rusak dan membuat antrian di line panjang karena truck sebelum keluar terlebih dahulu ditutupi terpal agar semen tidak rusak.

- Sopir tidak mengerti line / garis kuning, karena sopir dari perusahaan distributor masih kurang berpengalaman sehingga truk masuk ke line keluar dari garis kuning atau tidak di dalam garis kuning sehingga posisi truk tidak sejajar dengan mesin automatic.

- Personel kurang berpengalaman terhadap jalannya proses truck setting seperti kurang efektif dalam mengatur truck pada posisi yang tepat atau sejajar dengan mesin automatic.

- Pergantian shift yang tidak tepat waktu berpengaruh pada antrian truck yang dapat mengakibatkan antrian yang panjang.

- Alat kebersihan kurang berpengaruh terhadap kesehatan personel karena debu bekas tumpahan semen serta mengakibatkan garis kuning tidak terlihat akibat tertutupi oleh debu sehingga mengganggu jalannya proses setting truck.

- Lamanya persiapan bag / kantong semen berpengaruh pada proses pemuatan semen seperti waktu proses pemuatan semen dari roto packer ke mesin automatic serta berpengaruh pada antrian truck di line.

- Hanya menggunakan 6 spout dan rpm 2600 berpengaruhi pada kinerja roto packer tidak maksimal dan mempengaruhi kecepatan kinerja mesin automatic dalam proses pemuatan semen ke truck.

- Kantong semen tidak dalam kondisi baik berpengaruh pada waktu proses pemuatan semen seperti semen sobek atau tersangkut pada mesin automatic dan mengakibatkan hilangnya waktu proses pemuatan karena personel harus menyingkirkan semen yang pecah dari mesin automatic atau di truck.

- Sensor kotor berpengaruh pada semen pada saat di conveyor dan dapat mengakibatkan tabrakan antar semen sehingga semen sobek.

- Setting LM kurang berpengaruh pada kinerja mesin automatic seperti rolling sering macet sehingga conveyor tidak dapat berjalan atau semen terjepit di mesin automatic. Setelah itu menghitung probabilitas basic event pada FTA yang didapatkan secara subjektif, dalam hal ini digunakan kuesioner. Contoh perhitungan probabilitas cuaca saat musim hujan : Diketahui $\quad: \mathrm{P}=$ Probabilitas $\mathrm{N}=$ Jumlah Pernyataan $\mathrm{X}=$ Nilai Total Bobot

Dijawab: $\mathrm{P}=\frac{X}{N}$

$$
=\frac{12}{211}=0,06
$$

Untuk perhitungan probabilitas basic event yang lain didapatkan dengan cara yang sama. Jadi hasil perhitungan probabilitas setting truck dapat dilihat

\begin{tabular}{|c|c|c|}
\hline No & Basic Event & Probabilitas \\
\hline 1 & $\begin{array}{l}\text { Cuaca saat } \\
\text { musim hujan }\end{array}$ & 0,06 \\
\hline 2 & $\begin{array}{l}\text { Sopir tidak } \\
\text { mengerti line / } \\
\text { garis kuning }\end{array}$ & 0,11 \\
\hline 3 & $\begin{array}{l}\text { Personel } \\
\text { kurang } \\
\text { berpengalama } \\
\mathrm{n}\end{array}$ & 0,07 \\
\hline 4 & \begin{tabular}{ll}
\multicolumn{2}{l}{ Pergantian } \\
shift & yang \\
tidak & tepat \\
waktu &
\end{tabular} & 0,11 \\
\hline 5 & $\begin{array}{l}\text { Alat } \\
\text { kebersihan } \\
\text { kurang }\end{array}$ & 0,08 \\
\hline
\end{tabular}
pada tabel 6.

Tabel 6

Tabel Hasil Perhitungan Probabilitas Setting Truck 


\begin{tabular}{|c|l|c|}
\hline $\mathbf{6}$ & $\begin{array}{l}\text { Lamanya } \\
\text { persiapan bag } \\
\text { / kanto } \\
\text { ng } \\
\text { semen }\end{array}$ & 0,14 \\
\hline $\mathbf{7}$ & $\begin{array}{l}\text { Hanya } \\
\text { menggunakan } \\
6 \text { spout dan } \\
\text { rpm 2600 }\end{array}$ & 0,14 \\
\hline $\mathbf{8}$ & $\begin{array}{l}\text { Sensor kotor } \\
\mathbf{9}\end{array}$ & $\begin{array}{l}\text { Setting LM } \\
\text { kurang }\end{array}$ \\
\hline $\mathbf{1 0}$ & $\begin{array}{l}\text { Kantong } \\
\text { semen tidak } \\
\text { dalam kondisi } \\
\text { baik }\end{array}$ & 0,1 \\
\hline
\end{tabular}

Probabilitas Basic Event pada FTA didapatkan secara subjektif, dalam hal ini digunakan kuesioner. Kuesioner akan disebarkan kepada orang-orang yang berdasarkan ahli dibidangnya, lamanya bekerja pada bidang tersebut, (work experience), dan education untuk menentukan probabilitas dari event. Besarnya probabilitas setting truck pada bulan Januari - Maret 2018 adalah sebagai berikut:

a. Cuaca saat musim hujan mempunyai probabilitas sebesar 0,06 atau $6 \%$ terhadap setting truck.

b. Sopir tidak mengerti line / garis kuning mempunyai probabilitas sebesar 0,11 atau $11 \%$ terhadap setting truck.

c. Personel kurang berpengalaman mempunyai probabilitas sebesar 0,07 atau $7 \%$ terhadap setting truck.

d. Pergantian shift yang tidak tepat waktu mempunyai probabilitas sebesar 0,11 atau $11 \%$ terhadap setting truck.

e. Alat kebersihan kurang mempunyai probabilitas sebesar 0,08 atau $8 \%$ terhadap setting truck.

f. Lamanya persiapan bag / kantong semen mempunyai probabilitas sebesar 0,14 atau $14 \%$ terhadap setting truck.

g. Hanya menggunakan 6 spout dan rpm 2600 mempunyai probabilitas sebesar 0,14 atau $14 \%$ terhadap setting truck. h. Sensor kotor mempunyai probabilitas sebesar 0,1 atau $10 \%$ terhadap setting truck.

i. Setting LM kurang mempunyai probabilitas sebesar 0,1 atau $10 \%$ terhadap setting truck.

j. Kantong semen tidak dalam kondisi baik mempunyai probabilitas sebesar 0,09 atau $9 \%$ terhadap setting truck.

Jadi lamanya persiapan bag / kantong semen dan menggunakan 6 spout dan rpm 2600 yang memiliki probabilitas tertinggi sebesar 0,14 atau $14 \%$ terhadap setting truck.

Setelah mengetahui penyebab loading rate menurun karena disebabkan oleh beberapa faktor salah satunya lamanya setting truck yang memiliki persentase lebih besar dari beberapa faktor yang lainnya sehingga loading rate di automatic line packer menunjukan performa lebih kecil dari loading rate di manual line packer atau tidak sesuai dengan target perusahaan sebesar 53 ton/jam, maka disusun suatu rekomendasi atau ususlan tindakan perbaikan, pada tahap ini digunakan analisis $5 \mathrm{~W}+1 \mathrm{H}$ untuk membantu menetapkan pengembangan tindakan perbaikan performa loading rate khususnya di automatic line packer, secara umum dapat dilihat pada tabel 7. 
Tabel 7

Tabel Usulan Perbaikan

\begin{tabular}{|c|c|c|c|}
\hline No & Faktor & Penyebab Dominan & $\begin{array}{c}\text { Perbaikan } \\
\text { (Improve) }\end{array}$ \\
\hline \multirow[t]{3}{*}{1.} & Manusia & $\begin{array}{l}\text { Personel kurang } \\
\text { berpengalaman }\end{array}$ & $\begin{array}{l}\text { Melakukan } \\
\text { training kembali } \\
\text { personel } \\
\text { mengenai tata } \\
\quad \text { cara } \\
\text { setting truck sesuai } \\
\quad \text { SOP } \\
\text { perusahaan. }\end{array}$ \\
\hline & & $\begin{array}{lll}\text { Waktu } & & \\
\text { pergantian shift tidak } \\
\text { tepat } \\
\text { waktu }\end{array}$ & $\begin{array}{l}\text { Membuat } \\
\text { peraturan atau } \\
\text { memperketat waktu } \\
\text { pergantian shift } \\
\text { dengan } \\
\text { memberi sanksi } \\
\text { terhadap personel } \\
\text { yang melanggar. }\end{array}$ \\
\hline & & $\begin{array}{l}\text { Sopir truck kurang } \\
\text { berepengalaman }\end{array}$ & $\begin{array}{l}\text { Melakukan } \\
\text { sosialisasi terhadap } \\
\text { para distributor } \\
\text { untuk melatih sopir } \\
\text { truck agar mengerti } \\
\text { SOP } \\
\text { perusahaan. }\end{array}$ \\
\hline \multirow[t]{3}{*}{2} & Metode & $\begin{array}{l}\text { Lamanya persiapan bag / } \\
\text { kantong semen }\end{array}$ & $\begin{array}{l}\text { Melakukan } \\
\text { perawatan secara }\end{array}$ \\
\hline & & & $\begin{array}{l}\text { berkala } \\
\text { berkaitan dengan } \\
\quad \text { alat } \\
\text { pemindahan } \\
\text { bag dari gudang ke } \\
\text { roto serta } \\
\text { melatih kembali para } \\
\text { operator agar dapat } \\
\text { meningkatka n } \\
\text { produktivitas } \\
\text { kinerjanya. }\end{array}$ \\
\hline & & $\begin{array}{l}\text { Hanya menggunakan } 6 \\
\text { spout dan rpm } \\
2600\end{array}$ & \begin{tabular}{lr}
\multicolumn{3}{l}{ Melakukan } \\
penambahan spout \\
sebanyak 8 spout \\
dan menurunkan \\
rpm sebesar 2500 \\
serta & \\
melakukan training \\
kembali kepada \\
opertaor roto packer \\
agar \\
mengoperasi \\
kannya.
\end{tabular} \\
\hline
\end{tabular}

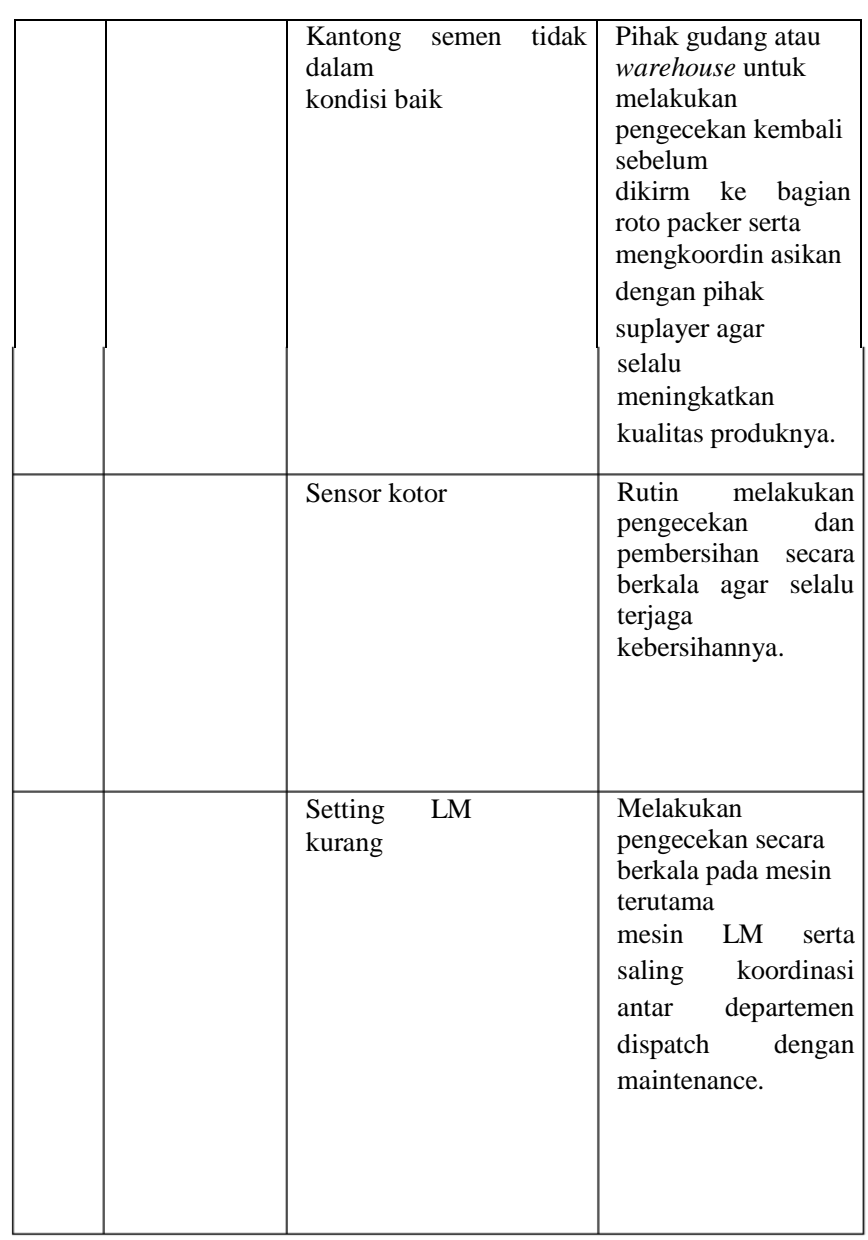




\section{SIMPULAN DAN SARAN}

Simpulan

- Jenis - jenis permasalahan yang sering terjadi pada loading rate yaitu disebabkan truck setting $(23,64 \%)$, trouble automatic loading machine $(21,82 \%)$, Trouble roto packer \& pengisian bin $(14,55 \%)$, trouble jalur conveyor belt \& roller $(12,12 \%)$, bag damage $(10,87 \%)$, trouble personel $(9,22 \%)$, trouble pengisian $(4,06 \%)$, kondisi lingkungan kerja $(3,33 \%)$ dan Empty bag preparation $(0,39 \%)$.

- Berdasarkan seven tools, prioritas perbaikan yang perlu dilakukan oleh PT. Cemindo Gemilang untuk meningkatkan performa loading rate khususnya di automatic line packer didapatkan faktor penyebab terbesar adalah faktor setting truck.

- Maka usulan perbaikan loading rate di packer loader di packer loader khususnya di automatic packer loader di PT. Cemindo Gemilang Gresik dengan menggunakan Seven Tools dan Fault Tree Analysis didapatkan sebagai berikut:

a. Melakukan training kembali personel mengenai tata cara setting truck sesuai SOP perusahaan.

b. Membuat peraturan atau memperketat waktu pergantian shift dengan memberi sanksi terhadap personel yang melanggar.

c. Melakukan sosialisasi terhadap para distributor untuk melatih sopir truck agar mengerti SOP perusahaan.

d. Melakukan perawatan secara berkala berkaitan dengan alat pemindahan bag dari gudang ke roto serta melatih kembali para operator agar dapat meningkatkan produktivitas kinerjanya.

e. Melakukan penambahan spout sebanyak 8 spout dan menurunkan rpm sebesar 2500 serta melakukan

training kembali kepada opertaor roto packer agar dapat mengoperasikannya.

f. Pihak gudang atau warehouse untuk melakukan pengecekan kembali sebelum dikirm ke bagian roto packer serta mengkoordinasikan dengan pihak suplayer agar selalu meningkatkan kualitas produknya. g. Rutin melakukan pengecekan dan pembersihan secara berkala agar selalu terjaga kebersihannya.

h. Melakukan pengecekan secara berkala pada mesin terutama mesin LM serta saling koordinasi antar departemen dispatch dengan maintenance.

Saran

- Perusahaan perlu menggunakan metode seven tools untuk dapat mengetahui jenis permasalahan yang sering terjadi dan faktor - faktor yang menjadi penyebab menurunnya performa loading rate automatic serta memfokuskan perbaikan pada jenis permasalahan yang memiliki jumlah besar atau dominan dalam proses loading rate di automatic line packer, yang disebabkan antara lain manusia, mesin, material dan lingkungan.

- Untuk mendapatkan performa loading sebesar 53 ton/jam, sebaiknya perngertian mengenai pentingnya produktifitas lebih ditanamkan lagi sampai ke tahap perkerja dan operator.

\section{DAFTAR PUSTAKA}

Amalia, Ridhati, Mohammad Arif Rohman, dan Cahyono Bintang Nurcahyo. - Analisa Penyebab Keterlambatan Proyek Pembangunan Sidoarjo Town Square Menggunakan Metode Fault Tree Analysis (FTA).॥ Jurnal Teknik ITS , 2012.

Fauzi, Syahrul dan Siregar. -Perbaikan Kualitas Menggunakan Metode Seven Tools dan Fault Tree Analysis (FTA) di PT. XYZ.\| Jurnal Departemen Teknik Kimia Fakultas Teknik Universitas Sumatera Utara, 2017: 2.

Gunawan. -Analisis Penyebab Defect Kapal Motor (KM) Pagerungan Pada Bagian Hull Construction (HC) Dengan Metode Failure Mode and Effect (FMEA) dan Fault Tree Analysis (FTA) Studi Kasus Pada PT. PAL.\| Jurnal Rekayasa dan Manjemen Industri Jurusan Teknik 
Industri Universitas Brawijaya, 2018: 12 Vol 3 No. 2.

Idris, Iswandi, Ruri Aditya Sari, Wulandari dan

Uthumporn. -Pengendalian

Kualitas

Tempe Dengan Metode Seven Tools.\| Jurnal Teknovasi, 2016.

Indonesia, Semen. Volume Penjualan Semen Indonesia. 2011.

http://www.semenindonesia.com/volumepenjua lan-semen-indonesia/ (diakses Juli 17, 2018).

Misrah, Sahrudin Barasandji dan Efendi Dg. Pawala. - Peningkatan Kemampuan Siswa Membuat Kalimat Tanya melalui Teknik 5W 1H di Kelas IV SD Inpres Lobu Gio.l Jurnal Kreatif Tadulako Online , 2014: Vol.1 No.4.

Mustofa, Heri Murnawan. -Perencanaan

Produktivitas Kerja dari Hasil Evaluasi Produktivitas dengan Metode Fishbone di Perusahaan Percetakan Kemasan PT. X.\| Teknik Industri HEURISTIC , 2014: Vol 1 No.1.

Putih, Semen Merah. Produk Semen Merah Putih. 2016. https://semenmerahputih.com (diakses Juli 21, 2018).

Render, Jay Heizer dan Barry. Prinsip - Prinsip Manajemen Operasi . Jakarta: Salemba Empat, 2001.

Santoso, Widodo. Asosiasi Semen Indonesia: Konsumsi Semen Tumbuh Hingga 17\% Januari 2018. 15
Februari 2018. http://www.bisnis.com (diakses Juli 16, 2018).

—. Perkembangan Industri Semen Indonesia. 17 November 2015.

http://www.apbiicma.org/wpcontent/uploa ds/2015/11/Presentasi-ASIESDM2015.pdf (diakses Juli 16, 2018).

Satria, Bayu dan Manfaat, Djauhar. -Aplikasi Formal Safety Assessment Untuk Penilaian Risiko Kecelakaan Pada Helipad FSO.\| Jurnal Teknik ITS, 2012: 3.

Suhandono,Ari . Bambang Purwanggono. - Analisis Proses Produksi Assembling Dan Pressing Pada PT Jati Luhur Agung Semarang Menggunakan Metode Fault Tree Analysis (FTA) Dan Barrier Analysis.\| 2014: 3.

Vesely. U.S. Nuclear Regulatory. Januari 1981. https://www.nrc.gov/docs/ML1007/ML10 0780465.pdf (diakses Juli 15, 2018)

Yemima, Ola, Darnah A. Nohe, dan Yuki Novia Nasution. - Penerapan Peta Kendali

Demerit dan Diagram Pareto Pada Pengontrolan Kualitas Produksi .\| Jurnal EKSPONENSIAL, 2014: Vol. 5. No.2.

Yuwono, Muhammad dan Agus. -Proses Produksi Dan Pengendalian Kualitas Produksi Cat Plastic Coating Di PT Propan Raya ICC.\| Jurnal PASTI, 2013: Vol. 9 No.2. 